\title{
PERSEPSI MAHASISWA TERHADAP KINERJA BEM DALAM MELAKUKAN KOORDINASI ORMAWA SELINGKUNGAN UNP
}

\author{
Wahib Assyahri \\ Jurusan Administrasi Publik, Fakultas Ilmu Sosial, Universitas Negeri Padang \\ wassyahri.wa@gmail.com

\section{Fachri Adnan} \\ Jurusan Administrasi Publik, Fakultas Ilmu Sosial, Universitas Negeri Padang \\ fachri.adnan@gmail.com

\section{Adil Mubarak} \\ Jurusan Administrasi Publik, Fakultas Ilmu Sosial, Universitas Negeri Padang \\ adilmubarak08@yahoo.co.id
}

\begin{abstract}
BEM (Student Executive Organization) was basically a campus executive institution that has a function to coordinate all student activities in the university environment through student organizations. However, the coordination that was carried out by BEM UNP with the student organizations within UNP for period for of 2016-2017 was not effective. The $B E M$ and the student organizations' work program went on singly without supporting and cooperating. The synergy among the student organizations has not yet reached. This study aims to analyze students' perceptions of BEM UNP performance in coordinating with the student organizations in UNP for period of 2016-2017. This study used descriptive quantitative method. The sample in this study were 100 students in UNP determined with Slovin formula and Proportionate Stratified Random Sampling technique. Data were collected through questionnaires with Likert scale measurements and interviews. The finding of this study showed that the students' perceptions about the coordination of BEM UNP with the students organizations in UNP for period of 20162017 were in the medium category with the mean of 2.68. Based on this result, BEM UNP needs more efforts to build up the communication and maintain the coordination with the student organizations, so that the synergy among the student organizations could be realized well.
\end{abstract}

Keywords: Perception; coordination; student organizations

How to Cite: Wahib Assyahri, M. Fachri Adnan, dan Adil Mubarak. 2018. Persepsi Mahasiswa Terhadap Kinerja BEM dalam Koordinasi Ormawa Selingkungan UNP. 2(2): pp. 136-146.

DOI: https://doi.org/10.24036/jess/vol2-iss2

\section{Pendahuluan}

Organisasi mahasiswa sangat penting peran dan artinya bagi setiap mahasiswa. Melalui organisasi mahasiswa dapat membentuk student government dalam 
rangka pengembangan dirinya. Eksistensi organisasi mahasiswa (Ormawa) dapat menjadi dan membangun salah satu nilai yang strategis dalam melatih jiwa kepemimpinan dan keberanian dalam mengungkapkan pendapat dan pengambilan keputusan.

Organisasi merupakan sistem peran, aliran aktivitas, dan suatu proses (pola hubungan kerja) yang melibatkan beberapa pihak untuk pelaksana tugas yang didesain dalam mencapai tujuan yang telah ditetapkan bersama. Robbins (dalam Torang, 2013) menyatakan bahwa organisasi merupakan suatu entitas sosial yang terkoordinir, terdiri atas dua orang atau lebih dengan batasan yang relatif dapat diidentifikasi, dan berfungsi secara berkelanjutan dalam mencapai tujuan dan sasaran bersama.

Dalam rangka pengembangan diri mahasiswa, khususnya dalam aspek kepemimpinan, maka organisasi kemahasiswaan sangatlah penting bagi perguruan tinggi. Di Universitas Negeri Padang (UNP), munculnya organisasi mahasiswa memberikan wadah tersendiri yang berusaha mengakomodir kebutuhan mahasiswa. Organisasi mahasiswa Universitas Negeri Padang diatur dalam peraturan Menteri Riset Teknologi dan Pendidikan Tinggi Republik Indonesia Nomor 67 Tahun 2016 yaitu Tentang Statuta UNP. Dalam peraturan selanjutnya organisasi mahasiswa berjalan berdasarkan Surat Keputusan Rektor UNP No: 55/J.41/KM/2004 tentang Amandemen Petunjuk Teknis Organisasi Kemahasiswaan Universitas Negeri Padang.

Fungsi koordinasi dalam usaha mencapai tujuan organisasi adalah mengarahkan semua aktivitas dari setiap unit/satuan kerja ke satu sasaran, yaitu tujuan organisasi. Tidak adanya koordinasi mengakibatkan unit-unit satuan kerja membentuk garis-garis paralel yang tidak akan bersatu (Wursanto, 2005). BEM pada dasarnya adalah suatu lembaga eksekutif kampus yang berfungsi mengkoordinasikan seluruh kegiatan kemahasiswaan internal di lingkungan universitas melalui Unit Kegiatan Mahasiswa (UKM) dan BEM Fakultas (BEMF). Kelancaran proses kegiatan lembaga kemahasiswaan akan menjadi lebih baik dengan adanya hubungan kerja antar lembaga kemahasiswaan. BEM UNP melaksanakan hubungan kerja bersama lembaga kemahasiswaan lainnya di lingkungan Universitas Negeri Padang dalam bentuk konsultatif dengan Majelis Perwakilan Mahasiswan (MPM), serta menjalin koordinasi dan komunikasi dengan UKM dan BEMF.

Pada kenyataanya koordinasi antara BEM UNP periode 2016-2017 dengan UKM dan BEM Fakultas se-UNP dalam pelaksanaan kegiatan kemahasiswaan belum terjalin secara optimal. Partisipasi UKM dan BEMF dalam mensukseskan Program BEM UNP masih minim dan pelaksanaan program kerja antara organisasi tersebut sering berjalan sendiri-sendir, sehingga kesatuan dan sinergisitas antara ormawa selingkungan UNP belum bisa dikatakan baik dan optimal.

Pelaksanaan koordinasi program yang dilakukan BEM UNP Periode 20162017 dengan Unit Kegiatan Mahasiswa belum signifikan dan baik. BEM UNP sebagai pemimpin dan pengarah kegiatan mahasiswa belum bisa merangkul dan mewadahi segenap kepentingan mahasiswa terutama dalam mengkomandoi Unit Kegiatan Mahasiswa. Begitupun koordinasi yang dilakukan BEM UNP Periode 
2016-2017 dengan BEM Fakultas se-UNP tidak terjalin dengan baik. Seharusnya koordinasi antara BEM Universitas dengan BEM Fakultas terjalin secara sistematis dan berkesinambungan. BEM Universitas sebagai Badan Eksekutif tertinggi harus bisa menyatukan pandangan terkait program strategis dalam satu periode kepengurusan bersama BEM Fakultas yang akan diterapkan kepada seluruh mahasiswa dan Unit Kegiatan Mahasiswa

Berdasarkan latar belakang masalah di atas, maka penulis telah melaksanakan penelitian di Universitas Negeri Padang mengenai persepsi mahasiswa tentang kinerja BEM UNP dalam melakukan koordinasi dengan organisasi mahasiswa selingkungan UNP periode 2016-2017. Rumusan masalah yang dikemukakan dalam penelitian ini adalah:

1. Bagaimanakah pelaksanaan koordinasi BEM UNP dengan organisasi mahasiswa selingkungan UNP periode 2016-2017?

2. Bagaimanakah persepsi mahasiswa tentang pelaksanaan koordinasi BEM UNP dengan organisasi mahasiswa selingkungan UNP periode 2016-2017?

\section{Tinjauan Kepustakaan}

\section{Persepsi}

Walgito (2005) menyatakan bahwa persepsi adalah suatu proses yang didahulukan terlebih dahulu melalui proses pengindraan (alat indra). Maksudnya adalah proses diterimanya stimulus oleh seseorang dengan menggunakan alat inderanya atau bisa juga disebut dengan proses sensoris. Stimulus tersebut diteruskan dan untuk proses selanjutnya itulah yang dinamakan proses persepsi. Sementara Krech dalam Thoha (1983) menyatakan bahwa persepsi merupakan proses kognitif yang komplek dan dapat menghasilkan suatu gambaran unik tentang kenyataan yang mana gambaran tersebut bisa berbeda dari kenyataanya.

Persepsi memiliki makna yang sangat penting bagi perilaku manusia. Perilaku individu didasari pada persepsi mengenai realitas dalam kehidupannya. Persepsi juga mengandung makna sebuah respon, tanggapan atau penerimaan langsung dari suatu hal sebagai proses dalam diri seseorang untuk dapat mengetahui berbagai hal melalui pancainderanya. Untuk itu dalam hal ini persepsi merupakan suatu proses kognisi yang menghasilkan informasi mengenai lingkungan sekitarnya. Dalam prosesnya, seseorang dapat memilih, mengevaluasi, dan mengorganisasikan lingkungannya serta memberikan penilaian yang bersifat positif atau negatif dalam suatu bentuk perilaku tertentu (Triatna, 2015).

Persepsi seseorang tentang sesuatu akan berbeda-beda. Ketika melihat sesuatu ataupun menerima stimulus, maka setiap individu memiliki persepsi yang berbeda walau terhadap objek yang sama. karena persepsi itu dipengaruhi oleh faktor-faktor tertentu. Faktor-faktor yang dapat mempengaruhi persepsi menurut Couto (2010) yaitu: 1) Tersedianya informasi sebelumnya; 2) Kebutuhan; dan 3) Pengalaman dari masa lalu. Sedangkan menurut Walgito (2005), persepsi dapat diukur melalui indikator-indikator sebagai berikut: 1) Penyerapan terhadap rangsang; 2) Pemahaman; dan 3) Penilaian atau evaluasi. Dalam Ilmu administrasi negara, persepsi dapat diartikan sebagai proses kognitif dan menghasilkan 
pemahaman dari kenyataan yang dipengaruhi oleh perasaan, lingkungan, kemampuan berpikir dan pengalaman-pengalaman individu.

\section{Kinerja}

Menurut Mangkunegara (2011) kinerja berasal dari kata Job Performance atau Actual Performance (prestasi kerja), yaitu hasil kerja secara kualitas dan kuantitas yang berhasil dicapai oleh seseorang dalam melakukan fungsinya berdasarkan tanggungjawab yang telah diberikan. Basri dan Rivai (2005) mengungkapkan bahwa kinerja atau prestasi kerja dapat didefinisikan sebagai prestasi yang berhasil dicapai oleh individu dalam melakukan tugas atau pekerjaan sesuai standar dan kriteria yang ditetapkan dari pekerjaan tersebut. Selain itu Bangun (2012) juga menjelaskan kinerja (performance) adalah hasil pekerjaan yang berhasil dicapai individu dalam pekerjaan berdasarkan persyaratan dari pekerjaan tersebut (job requirement).

Di sisi lain, Sinambela, dkk. (dalam Pasolong (2010) memberikan pengertian bahwa kinerja adalah kemampuan individu dalam melakukan pekerjaan dengan keahlian tertentu. Pengertian dari kinerja juga dikemukakan oleh Widodo dalam Pasolong (2010) yang mengatakan bahwa kinerja merupakan suatu kegiatan dan disempurnakan melalui keahlian sesuai tanggungjawab untuk mencapai hasil yang diharapkan. Dari uraian di atas dapat dipahami bahwa kinerja adalah hasil yang dicapai individu baik secara kualitas dan kuantitas dalam melakukan tugasnya sesuai dengan tanggung jawab yang diberikan kepadanya.

Menurut Pasolong (2010), faktor-faktor yang mempengaruhi kinerja dari suatu organisasi yaitu: 1) Kemampuan, 2) Kemauan atau motivasi, 3) Energi, 4) Teknologi, 5) Kepemimpinan, 6) Kompensasi, 7) Kejelasan tujuan, dan 8) Keamanan. Sementara menurut Dwiyanto (dalam Harbani, 2010) untuk mengukur kinerja birokrasi publik, maka dapat digunakan indikator-indikator sebagai berikut: 1) Produktivitas, 2) Kualitas layanan, 3) Responsivitas, 4) Responsibilitas, dan 5) Akuntabilitas

\section{Koordinasi}

Ndraha (2003) menyatakan bahwa koordinasi merupakan kegiatan yang dilakukan oleh pihak-pihak yang sederajat untuk saling memberikan informasi dan mengatur beberapa hal secara bersama, sehingga di satu sisi proses pelaksanaan tugas dan keberhasilan pihak yang satu tidak menganggu pihak yang lain, dan dapat saling mendukung baik secara langsung maupun tidak langsung. Secara normatif, koordinasi merupakan kewenangan untuk menggerakkan, menyerasikan, menyelaraskan dan menyeimbangkan berbagai kegiatan yang spesifik atau berbeda-beda, agar terarah pada pencapaian tujuan tertentu telah ditetapkan.

Djamin (dalam Hasibuan, 2011) mengartikan koordinasi sebagai suatu usaha kerja sama antar badan, instansi, atau unit dalam pelaksanaan tugas-tugas tertentu sedemikian rupa, sehingga terdapat saling mengisi, membantu, dan melengkapi. White (dalam Syafiie, 2006) memberikan definisi bahwa koordinasi merupakan penyesuaian diri (adjustment) dari masing-masing bagian, dan usaha untuk menggerakkan serta mengoperasikan bagian-bagian tersebut pada waktu yang 
tepat (parts in time), sehingga masing-masing bagian dapat saling memberikan sumbangan pada keseluruhan hasil. Berdasarkan definisi di atas dapat disimpulkan bahwa koordinasi adalah proses menyerasikan dan menyelaraskan kegiatankegiatan berupa pelaksanaan kegiatan antar organisasi untuk saling memberi informasi agar semuanya dapat terarahkan pada pencapaian tujuan yang telah ditetapkan.

Dengan memandang koordinasi melalui proses manajemen, maka menurut Handayaningrat (1989) yang perlu diukur dalam koordinasi adalah: 1) Komunikasi, 2) Kesadaran akan pentingnya koordinasi, 3) Kompetensi partisipan, 4) Kesepakatan, komitmen, dan insentif koordinasi, dan 5) Kontinuitas perencanaan. Selanjutnya Abdurahman (dalam Rakhmad, 2016) menetapkan indikator koordinasi dalam mengukur kinerja organisasi publik sebagai berikut: 1) Efisiensi, 2) Satu Arah, 3) Partisipasi, 4) Ketepatan, dan 5) Koordinasi Strategis

\section{Organisasi Mahasiswa}

Rivai (2012) menyatakan bahwa organisasi merupakan suatu wadah yang membuat masyarakat dapat meraih hasil yang sebelumnya tidak dapat dicapai secara sendiri-sendiri, organisasi merupakan suatu unit yang terkoordinasi dan terdiri dari dua orang atau lebih, berfungsi mencapai suatu tujuan dan sasaran tertentu. Sementara organisasi mahasiswa intra-kampus merupakan organisasi kemahasiswaan yang mempunyai kedudukan resmi di lingkup perguruan tinggi dan diatur dalam surat keputusan Menteri Pendidikan Nasional dan Kebudayaan No.155/U/1998 Tentang Pedoman Umum Organisasi Kemaha-siswaan.

Organisasi digunakan sebagai tempat/wadah untuk berkumpul, berdiskusi, dan bekerjasama dalam mencapai tujuan. Organisasi kemahasiswaan merupakan wadah dan sarana bagi mahasiswa dalam belajar, berkumpul, dan mengembangkan setiap potensi-potensi kepemimpinannya (Kepmen Dikbud nomor:155/U/1998). Organisasi mahasiswa di UNP berjalan berdasarkan Surat Keputusan Rektor Universitas Negeri Padang No: 55 / J.41 / KM / 2004 tentang Amandemen Petunjuk Teknis Organisasi Kemahasiswaan Universitas Negeri Padang.

Di Universitas Negeri Padang (UNP) organisasi mahasiswa tingkat universitas terdiri dari:

1) Majelis Perwakilan Mahasiswa (MPM) sebagai organisasi legislatif dan normatif, penampung, penganalisis dan penyalur aspirasi mahasiswa di tingkat universitas.

2) Badan Eksekutif Mahasiswa (BEM) sebagai lembaga pelaksana kegiatan (eksekutif) tingkat universitas.

3) Unit Kegiatan Mahasiswa (UKM) sebagai lembaga pelaksana kegiatankegiatan, penalaran dan keilmuan, minat dan kegemaran, kesejahteraan mahasiswa dan kepedulian sosial.

4) Badan Eksekutif Mahasiswa Fakultas (BEMF) sebagai lembaga pelaksana kegiatan (eksekutif) tingkat fakultas. 


\section{Metode Penelitian}

Penelitian ini merupakan penelitian deskriptif dengan menggunakan pendekatan kuantitatif. Penelitian ini dilakukan di lingkungan Universitas Negeri Padang. Populasi dalam penelitian ini adalah mahasiswa Universitas Negeri Padang tahun masuk 2015 dan 2016. Pengambilan sampel dalam penelitian ini menggunakan rumus Slovin dengan tingkat kesalahan 10\% dan menghasilkan 100 sampel mahasiswa. Selain itu penentuan sampel dalam penelitian ini dilakukan dengan menggunakan teknik Proportionate Stratified Random Sampling.

Pengumpulan data dalam penelitian ini menggunakan angket yang dibagikan kepada mahasiswa. Sedangkan variabel dalam penelitian ini merupakan variabel tunggal yaitu koordinasi. Pengolahan data dalam penelitian ini menggunakan SPSS versi 22. Setelah diolah data kemudian dianalisis dengan menggunakan model analisis interaktif dengan langkah-langkah: reduksi data, display data, dan penarikan kesimpulan.

\section{Hasil Penelitian dan Pembahasan}

Sebagaimana telah dikemukakan dalam bagian pendahuluan, penelitian ini ingin menjawab dua pertanyaan penelitian atau rumusan masalah. Rumusan masalah pertama adalah: bagaimanakah pelaksanaan koordinasi BEM UNP dengan organisasi mahasiswa selingkungan UNP periode 2016-2017? Untuk jawab pertanyaan ini dapat dilihat dari hasil wawancara peneliti dengan salah seorang pengurus organisasi mahasiswa di UNP yaitu:

Koordinasi yang terjalin antara BEM UNP periode 2016-2017 dengan ormawa tidak efektif. Hal ini terlihat jelas melalui pelaksanaan organisasi BEM dan organisasi mahasiswa lainnya yang berjalan sendiri-sendiri tanpa saling koordinasi dan bekerja sama, bahkan program kerja antara BEM UNP dengan UKM memiliki banyak kemiripan. Masing-masing ormawa mempertahankan sikap egoismenya, sehingga sinergisitas antar ormawa masih belum terwujud.

Hal ini senada dengan hasil wawancara peneliti dengan salah satu ketua Unit Kegiatan Mahasiswa, yang mengatakan bahwa:

... komunikasi dan sillaturrahim antara BEM dengan UKM pada periode 2017 jarang dilakukan. Koordinasi tidak berjalan lancar serta program kerja yang berjalan sendiri-sendiri tanpa adanya koordinasi satu sama lain.

Dari wawancara di atas dapat dipahami bahwa komunikasi dan silaturrahim yang jarang dilakukan oleh pengurus menjadi kendala dalam melaksanakan koordinasi. Konsistensi terhadap koordinasi di setiap pelaksanaan program kerja sangatlah perlu dilakukan sehingga suatu kegiatan akan sukses terlaksana. Hal ini antara lain 
diungkapkan oleh Sekretaris Umum BEM FMIPA Periode 2016-2017 yang menyebutkan bahwa:

...BEM sebagai lembaga eksekutor di Universitas harusnya menjadi teladan dalam melaksanakan kegiatan sehingga ormawa lain dapat meniru. Selama ini dalam kepengurusan kami tidak ada evaluasi dari pihak BEM mengenai pemecahan masalah terkait miskomunikasi BEM dengan ormawa. Harus adanya pertemuan secara berkesinambungan antara BEM dengan Ormawa dalam melaksanakan koordinasi.

Berdasarkan wawancara dengan beberapa pengurus organisasi mahasiswa di atas dapat disimpulkan bahwa koordinasi yang terjalin antara BEM dengan Ormawa tidak berjalan dengan lancar, yaitu tidak adanya jadwal rutin pertemuan ormawa dalam berkoordinasi secara berkesinambungan, masih adanya miskomunikasi antar ormawa dan program kerja yang berjalan sendiri-sendiri tanpa koordinasi. Kendala yang dihadapi antara lain adalah: 1) Prioritas Waktu yaitu, kesibukan pengurus organisasi sehingga sulit menghadirkan pengurus dalam pertemuan dan rapat; 2) Orientasi pribadi pengurus, yaitu kurangnya perhatian dan kesadaran penting pengurus dalam berkoordinasi; 3) Komunikasi antar pengurus kurang baik; dan 4) Kurang konsisten, yaitu tidak menjalankan peraturan yang berlaku dengan baik tentang tugas dan fungsi dalam menjalankan koordinasi.

Selanjutnya rumusan masalah kedua adalah: bagaimanakah persepsi mahasiswa tentang kinerja BEM UNP dalam melakukan koordinasi dengan organisasi mahasiswa selingkungan UNP periode 2016-2017? Untuk menjawab pertanyaan penelitian ini dapat dilihat hasil analisis data temuan penelitian seperti disajikan pada Tabel 1 berikut.

Tabel 1. Deskripsi Variabel Koordinasi

\begin{tabular}{lccc}
\hline \multicolumn{1}{c}{ Item Pernyataan } & Mean & Persentase & Keterangan \\
\hline Efisiensi (X1) & 2.72 & $61 \%$ & Tinggi \\
Satu Arah (X2) & 2.73 & $64 \%$ & Tinggi \\
Partisipasi (X3) & 2.67 & $44 \%$ & Sedang \\
Ketepatan (X4) & 2.74 & $54 \%$ & Sedang \\
Koordinasi Strategis (X5) & 2.54 & $40 \%$ & Sedang \\
\hline \multicolumn{1}{c}{ Rata-rata Variabel } & $\mathbf{2 . 6 8}$ & $\mathbf{4 5 \%}$ & Sedang \\
\hline
\end{tabular}

Berdasarkan Tabel 1 di atas dapat dijelaskan bahwa nilai rata-rata (mean) dari variabel koordinasi adalah sedang dan nilai rata-ratanya sebesar 2.68 sebanyak 45 responden atau 45\% dari 100 responden. Jadi, dapat dipahami bahwa sebagian responden menilai aspek koordinasi dalam kategori sedang, karena nilai rata-rata dan jawaban dari responden yang berada pada rentang 41\%-60\% termasuk ke 
dalam kategori sedang. Perhitungan ini diperoleh dari setiap indikator koordinasi dan diperoleh rata-rata: a) Efisiensi dengan nilai $61 \%$; b) Satu arah dengan nilai $64 \%$; c) Partisipasi dengan nilai $44 \%$; d) Ketepatan dengan nilai $54 \%$; dan e) Koordinasi strategis dengan nilai $45 \%$.

Berdasarkan hasil penelitian secara kualitatif bahwa pelaksanaan koordinasi organisasi yang dilakukan Badan Eksekutif Mahasiswa dengan Organisasi Mahasiswa selingkungan UNP periode 2016-2017 tidak berjalan lancar, yaitu tidak adanya jadwal rutin pertemuan ormawa dalam berkoordinasi secara berkesinambungan, masih adanya miskomunikasi antar ormawa dan program kerja yang berjalan sendiri-sendiri tanpa koordinasi dan kerjasama. Pelaksanaan koordinasi organisasi yang dilakukan yaitu berupa penjelasan secara lisan kepada koordinator organisasi kemahasiswaan, sosialisasi peraturan dan diskusi organisasi. Namun hal ini tidak berjalan baik.

Menurut Terry dan Rue (1999) koordinasi organisasi dapat dilaksanakan dengan cara memberikan keterangan langsung dan secara bersahabat, mensosialisasikan tujuan kepada para anggota, mendorong anggota untuk bertukar pikiran, mendorong anggota untuk berpartisi-pasi dalam tingkat perumusan dan penciptaan sasaran. Koordinasi sangatlah dibutuhkan dalam setiap perumusan dan penciptaan sasaran. Komunikasi adalah kunci utama dalam tercapainya koordinasi efektif. Koordinasi merupakan suatu pemrosesan informasi, di sini peran pemimpin dibutuhkan dalam melaksanakan tugas dan fungsinya dalam bidang pengontrolan, pengawasan dan evaluasi. Hubungan dan kelancaran informasi antara pimpinan dengan bawahan pun juga sangat diperhatikan agar dalam pelaksanaan tugas tidak terjadi kesalahan informasi ataupun tekanan dalam bekerja.

Dalam melaksanakan koordinasi diperlukanlah prinsip-prinsip. Menurut Terry dan Rue (1999), koordinasi antar bagian dan antar individu di dalam organisasi akan dapat tercapai apabila diikuti dengan tiga prinsip yaitu: 1) prinsip kontak langsung, yaitu koordinasi harus dicapai melalui hubungan antar individu baik hubungan horizontal maupun vertikal; 2) prinsip penekanan akan pentingnya koordinasi, koordinasi yang kurang baik akan dapat menimbulkan kesimpangsiuran di dalam organisasi; dan 3) hubungan timbal balik di antara faktor-faktor yang ada. Setiap individu yang bekerja bersama-sama dalam kondisi pekerjaan tertentu, akan saling memberikan pengaruh. Oleh karena itu, mereka harus membuka kesempatan untuk saling tukar informasi.

Komunikasi adalah kunci utama dari pelaksanaan koordinasi yang efektif. Koordinasi secara langsung tergantung pada perolehan, penyebaran dan pemrosesan informasi. Semakin besar ketidakpastian tugas yang dikoordinasi, maka semakin tinggi informasi dibutuhkan. Pada dasarnya koordinasi merupakan pemrosesan informasi. Menurut Wursanto (2005) koordinasi dapat dijalankan dengan berbagai cara: memanfaatkan saluran media/media komunikasi, mengangkat koordinator, membuat simbol, tanda-tanda, atau kode-kode tertentu.

Koordinasi merupakan salah satu fungsi organik yang dapat diartikan sebagai suatu fungsi yang harus dilaksanakan sebab apabila fungsi ini tidak dilaksanakan akan mempengaruhi fungsi-fungsi manajemen lainnya. Fungsi koordinsi bertujuan untuk mewujudkan kerjasama yang sebaik-baiknya agar 
pelaksanaan dapat terlaksana dengan baik dan sinkron sehingga apa yang ditetapkan dapat terwujud.

Selanjutnya hasil penelitian ini secara kuantitatif menunjukkan bahwa persepsi mahasiswa tentang koordinasi BEM UNP dengan ormawa selingkungan UNP periode 2016-2017 berada pada kategori sedang dengan nilai mean yang diperoleh sebesar 2.68. Jawaban responden yang berada di atas mean 2.68 sebanyak 45 dengan persentase $45 \%$ dari 100 responden.

Hasil penelitian di atas sepenuhnya mendukung teori yang dikemukakan oleh Awaluddin Djamin (dalam Hasibuan, 2011) yaitu koordinasi sangat penting dalam pelaksanaan organisasi karena koordinasi merupakan suatu usaha yang mampu menyelaraskan pelaksanaan tugas maupun kegiatan dalam suatu organisasi. Koordinasi dimaksudkan sebagai usaha menyatukan kegiatan-kegiatan dari satuan-satuan kerja organisasi dengan cara yang berhasil guna dan berdaya guna (efektif dan efisien), sehingga organisasi bergerak sebagai kesatuan yang bulat guna melaksanakan seluruh tugas organisasi untuk mencapai tujuannya. Ndraha (2003) menyatakan bahwa tujuan koordinasi untuk menciptakan dan memelihara efektivitas dan efisiensi organisasi setinggi mungkin melalui sinkronisasi, penyerasian, kebersamaan, dan kesinambungan antar berbagai dependen suatu organisasi. Handayaningrat (1985) juga menyatakan bahwa indikator pengukuran koordinasi dalam proses manajemen organisasi yaitu komunikasi dan partisipasi, ada tidaknya informasi dan alur informasi serta pihakpihak yang terlibat.

Hasil penelitian ini juga sejalan dengan penelitian sebelumnya seperti penelitian oleh Jaenal Mutakim (2015) dengan judul "Persepsi Mahasiswa terhadap Pengembangan Kegiatan Badan Eksekutif Mahasiswa di Fakultas Ilmu Pendidikan Universitas Jakarta". Hasil penelitian Jaenal Mutakim ini menunjukkan bahwa rata-rata persentase persepsi mahasiswa terhadap BEM FIP UNJ dalam melakukan koordinasi program kerja dengan Unit Kegiatan Mahasiswa (UKM) sebesar 65,9\%. Hal ini menunjukkan bahwa responden memiliki persepsi yang baik terhadap pelaksanaan koordinasi BEM FIP UNJ dengan UKM.

\section{Penutup}

Berdasarkan hasil penelitian dan pembahasan yang telah diuraikan di atas, dapat disimpulkan bahwa:

1. Berdasarkan hasil penelitian dan pembahasan secara kualitatif dapat diketahui bahwa koordinasi yang terjalin antara BEM UNP periode 2016-2017 dengan ormawa tidak efektif. Hal ini terlihat jelas melalui sikap BEM dan ormawa lainnya yang berjalan sendiri-sendiri tanpa saling mendukung dan bekerja sama, bahkan program kerja antara BEM UNP dengan UKM memiliki banyak kemiripan. Masing-masing mempertahankan sikap egonya, sehingga sinergisitas antar ormawa masih belum terwujud. Kendala yang dihadapi adalah waktu, orientasi pribadi pengurus, komunikasi antar pengurus kurang baik, serta tidak konsisten terhadap peraturan yang berlaku. 
2. Berdasarkan hasil analisis data secara kuantitatif maka dapat disimpulkan bahwa persepsi mahasiswa tentang koordinasi BEM UNP dengan ormawa selingkungan UNP periode 2016-2017 berada pada kategori sedang dengan nilai mean yang diperoleh sebesar 2.68. Jawaban responden yang berada di atas mean 2.68 sebanyak 45 dengan persentase $45 \%$ dari 100 responden.

3. Berdasarkan hasil analisis data secara kualitatif dan kuantitatif maka dapat disimpulkan bahwa pelaksanaan koordinasi BEM UNP dengan organisasi mahasiswa selingkungan UNP periode 2016-2017 dinilai tidak baik.

Berdasarkan hasil penelitian dan kesimpulan yang telah diuraikan di atas, maka penulis mengemukakan saran-saran sebagai berikut:

1. BEM UNP harus lebih meningkatkan lagi perannya dalam mewadahi, mensosialisasikan dan mengikutsertakan seluruh mahasiswa dalam programprogram kerja BEM UNP serta lebih membangun komunikasi dan menjaga koordinasi dengan organisasi mahasiswa selingkungan UNP sehingga bisa terwujud sinergisitas antar ormawa selingkungan UNP.

2. Peneliti menyadari bahwa hasil penelitian ini masih memiliki kelemahan tertentu, maka dari itu diharapkan kepada peneliti selanjutnya untuk lebih menyempurnakan penelitian ini dengan cara melakukan penelitian yang lebih mendalam dan dengan melibatkan berbagai variabel lain.

\section{DAFTAR KEPUSTAKAAN}

Bangun, Wilson. (2012). Manajemen Sumber Daya Manusia. Jakarta: Erlangga.

Basri \& Rivai, V. (2005). Performance Appraisal: Sistem yang Tepat Untuk Menilai Kinerja Karyawan dan Meningkatkan Daya Saing Perusahaan. Jakarta: PT. Raja Grafindo Persada.

Couto, Nasbahry. (2010). Psikologi Persepsi dalam Desain Komunikasi Visual. Padang: UNP Press.

Handayaningrat, Soewarno. (1989). Pengantar Studi Ilmu Administrasi dan Managemen. Jakarta: PT Gunung Agung.

Hasibuan, Malayu. (2011). Manajemen: Dasar, Pengertian, dan Masalah. Jakarta: Bumi Aksara.

Jaenal Mutakim. (2015). Persepsi Mahasiswa Terhadap Pengembangan Kegiatan Badan Eksekutif Mahasiswa di Fakultas Ilmu Pendidikan Universitas Negeri Jakarta. Jurnal EMPOWERMENT, Vol.4 No.2 2015, ISSN No. 2252-4738

Mangkunegara, Anwar Prabu. (2011). Manajemen Sumber Daya Manusia Perusahaan. Bandung: PT Remaja Rosdakarya.

Ndraha, Taliziduhu. (2003). Kybernologi: Ilmu Pemerintahan Baru. Jakarta: PT Rineka Cipta.

Pasolong, Harbani. (2010). Kepemimpinan Birokrasi. Bandung: Alfabeta.

Peraturan Menteri Riset Teknologi dan Pendidikan Tinggi Republik Indonesia Nomor 67 Tahun 2016 tentang Statuta Universitas Negeri Padang. 
Rakhmat, Wahid. (2016). Pengaruh Koordinasi terhadap Kinerja Petugas Pemungut Pajak Bumi dan Bangunan di Kelurahan Sukagalih Kecamatan Tarogong Kidul Kabupaten Garut. Jurnal Pembangunan dan Kebijakan Publik, Vol.7 No.1 2016, ISSN: 2087-1511.

Rivai, Mulyadi. (2012). Kepemimpinan dan Perilaku Organisasi. Jakarta: PT Raja Grafindo Persada

Surat Keputusan Menteri Pendidikan Nasional dan Kebudayaan No.155/U/1998 Tentang Pedoman Umum Organisasi Kemahasiswaan

Surat Keputusan Rektor Universitas Negeri Padang No: 55 / J.41 / KM / 2004 tentang Amandemen Petunjuk Teknis Organisasi Kemahasiswaan Universitas Negeri Padang

Syafiie, Inu Kencana. (2006). Ilmu Administrasi Publik. Jakarta: PT Rineka Cipta.

Terry, G.R dan L.W. Rue. (1999). Dasar-Dasar Manajemen. Jakarta: Bumi Aksara.

Thoha, Miftah. (1983). Perilaku Organisasi. Konsep Dasar dan Aplikasinya. Jakarta: PT Raja Grafindo Persada.

Torang, Syamsir. (2013). Management. Bandung: Alfabeta.

Triatna, Cepi. (2015). Perilaku Organisasi. Bandung: PT Remaja Rosdakarya.

Walgito, Bimo. (2005). Pengantar Psikologi Umum. Yogyakarta: Penerbit Andi.

Wursanto. (2005). Dasar-Dasar Ilmu Organisasi. Yogyakarta: Penerbit Andi. 